\title{
THE DYNAMIC IMPACT OF GOVERNMENT EXPENDITURE IN EDUCATION ON ECONOMIC GROWTH
}

\author{
Norimah Rambeli* \\ Faculty of Management and Economics, Universiti Pendidikan Sultan Idris \\ Dayang Affizzah Awang Marikan \\ Faculty of Economics and Business Universiti Malaysia Sarawak \\ Jan M. Podivinsky \\ School of Economic, Social and Political Science, University of Southampton \\ Rosilawati Amiruddin \\ Faculty of Business and Management, Universiti Teknologi MARA \\ Ismadi Ismail \\ Faculty of Business and Management, Universiti Teknologi MARA
}

\begin{abstract}
The focal aim of this study is to examine the validation of education-led economic growth hypothesis in Malaysia under the recovery period following the 2008 world economic crisis. Specifically, this study implemented the augmented Cobb-Douglas model in order to observe the dynamic relationship between selected variables including, industrial production index, gross fixed capital formation, employment, government spending on education and broad money supply. This study adopted the Vector Error Correction Model (VECM) in analysing the dynamic impact between variables and generally supports the education-led growth hypothesis in the short and long run. Specifically the study corroborates the bidirectional causality between education spending and economic growth, and vice versa, in the short run. The result also reveals that long-run equilibrium relationship exists between government expenditure in education and economic growth in Malaysia during post-crisis recovery regime. The education-led growth hypothesis can thus be inferred for the economy following crisis. The government should thus be advised that increasing education sector spending should increase post-crisis economic growth in both the short and long run. This is further strengthened by Granger causality test result which suggests unidirectional causality that runs from financial variable to economic growth. It is accordingly suggested that financial variable is a determinant of government spending on education in the aftermath of the economic crisis. Additionally, the study also supports the role of capital and employment on economic growth in the long term. By implication, the study suggests that financial planning as related to national education policies must be carefully and meticulously crafted, to ensure future success. This is linked to the investment in human capital which includes education expenditure at different levels that is essentially important to national long-term planning. The specific financial planning for human capital development is therefore very important to ensure the expenditure incurred contributes to sustainable economic development in Malaysia in the long term.
\end{abstract}

\footnotetext{
- Corresponding author: Economics Department, Faculty of Management and Economics, Universiti Pendidikan Sultan Idris (UPSI), 35900, Tanjong Malim Perak. Malaysia; Email: norimah@ fpe.upsi.edu.my
} 
Keywords: Education-Led Growth Hypothesis, Economic Growth, Education Expenditure, Vector Error Correction Model.

Received: 24 March 2021

Accepted: 27 September 2021

https://doi.org/10.33736/ijbs.4318.2021

\section{INTRODUCTION}

Education can be defined as the process of facilitating learning, or the achievement of knowledge, skills, values, morals, beliefs, and habits. This process can occur in the long- and short-term (Rambeli et al., 2020). Education factors in Malaysia were shown to contribute to the production of better human capital according to numerous studies at the microeconomics level, including Raja Aris, (2021), Abdullah et al. (2020) and Mohamed Noor et al. (2016). At the same time, from the macroeconomic perspective in aggregate level, the education process has been steadily developing and positively enhancing its impact on economic growth ever since Malaysia's independence in 1957 (Rambeli et al., 2020; Hashim et al., 2020). Several studies provided empirical evidence including Idrees and Siddiqi (2013); Hanif and Arshed (2016); Rahman, (2011); Afzal et al. (2010); Eggoh et al. (2015); and Kangjuan et al. (2017). According to Rambeli et al. (2020), from 1998 until 2018 government spending on education increased positively, parallel with the increase in national gross domestic product. According to Ismail (1998), this spending may influence economic growth, either positively or otherwise, depending on the economic situation. Studies by Frank (2018), Islam et al. (2016), Mallick and Dash (2015), Abugamea (2017), Rambeli et al. (2016a), Kouton (2018), further concurred with the finding that education expenditure significantly impact economic growth of the country. With reference to Ismail (1998), Han and Lee (2019) and Rambeli et al. (2020) believed that growth is influenced by highly educated and skilled human capital, thus indicating that individuals have the capability to increase level of productivity and, in turn, enhance economic performance. Figure 1 shows the performance of government spending on education spanning 2010 to 2020.

Figure 1: Government spending on Education in Malaysia (1990-2020)

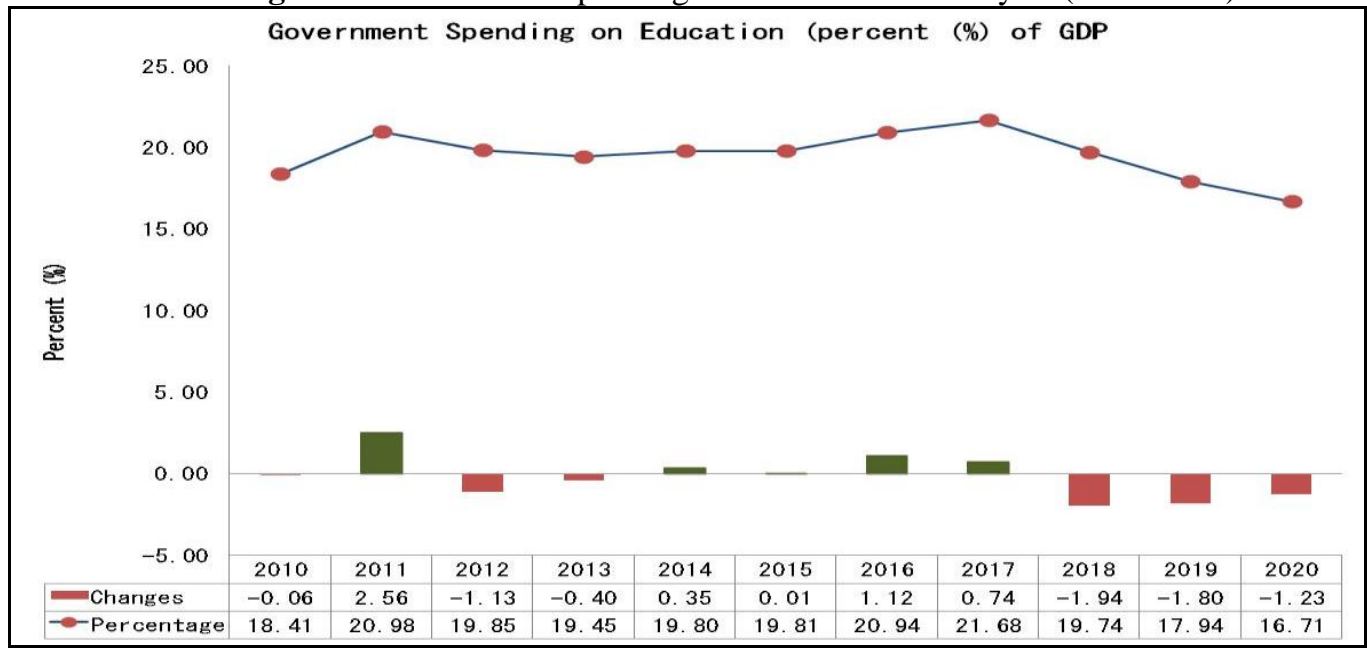


As shown in Figure 1, government spending on education in Malaysia experiences its ups and downs over the period 2010 to 2020 , ever since her recovery from the world economic crisis in 2008. Data from the Department of Statistic, Malaysia (DOSM), showed that the education expenditure in the GDP increased from $18.41 \%$ to $20.98 \%$ (an increment of $2.56 \%$ ). The data however showed a slight decrease in spending between 2011 and 2013, down from 19.85\% in 2012 to $19.45 \%$ in 2013 . This was followed with an upward trend from 2014 to 2017, with a peak in 2016, at 20.94\%. Beyond this was a decline from 2018 to 2020, with negative rates of $1.94 \%$ in $2018,-1.80 \%$ in 2019 and $-1.23 \%$ in 2020 . The data showed that the flux in education spending may significantly impact economic growth in Malaysia, both in the short and long term. The motivation of this empirical study is to explore the relationship between government spending on education and the country's economic growth, specifically in the post-crisis period of World Crisis in 2008. It will be based on the education-led growth hypothesis.

In order to understand the role of education on economic growth as stated above, this study adopted the education-led growth hypothesis through the application of the Cobb Douglas production function theory. This theory was based on the empirical study by the American manufacturing pioneer Cobb and Douglas (1928). According to the production functions, capital and labour exerts significant impact on the country's production. In this study capital is represented by gross fixed capital formation. Iheanacho (2017) and Hashim et al. (2020) among others, had claimed that capital will significantly impact economic growth. Labour force is represented by employment (Yeisa \& Rani, 2020; Shahid, 2014) and it is expected to give positive relationship, in the short and long term, with productivity. In other words, when labour involvement in the productivity process is increased it will lead to growth in production.

This study further expands the basic model of Cobb Douglas production function theory by including the impact of government spending on education, and financial variable. As previously stated, government spending on education has led to economic growth in the country (Rambeli, et al., 2020; Kouton, 2018; Kangjuan et al., 2017). This is further supported by many empirical studies conducted in developing and developed countries where government spending in education was shown to be a significant catalyst in being the driver of economic growth (Idrees \& Siddiqi, 2013; Kouton, 2018; Mallick, Das \& Prandhan, 2016; Mercan \& Sezer, 2014). Additionally, financial variable is represented by broad money supply (Dingela \& Khobai, 2017; Hussain \& Haque, 2017). It is believed to be able to exert positive impact on economic performance both in the short and long term.

According to Barakat et al. (2010) and Thomas et al. (2004), the impact of education on growth is unpredictable under the condition of recovery following the economic crisis, specifically this study focused on the world economic crisis of 2008. And as mentioned earlier, this post-crisis period was not sufficiently examined by researchers especially in the case of Malaysia. Therefore, this study takes the opportunity to test the education-led growth hypothesis through focusing on and exploring suitable recovery regime for the country. According to Heyneman (1990), at a time when the education system has expanded in size to a point unprecedented in history, a crisis of equivalent proportions will affect the ability of the system to operate. This crisis has adversely affected the quality of education in developing countries including the potential of education as a driver to the country's economic growth. These findings were supported by later studies by Barakat et al. (2010) in Europe and Thomas et al. (2004) in Indonesia, Nambissan (2013) in India, Bamigboye et al. (2016) in Nigeria. They emphasized that 
the relationship between education and economic growth is unpredictable and the association in the post-crisis period can be negative, positive or ambiguous. This study was thus aimed at testing the education-led growth hypothesis under the condition of recovery following the aftermath of the world economic crisis. For the test several macroeconomic variables were selected, namely gross fixed capital formation (CAP), employment (EMP), government spending in education (EDU) and financial indicator (FIN) on Malaysian economic growth.

The potential contribution from this study can be divided into two aspects. Firstly, the study extends the existing literature through employing the linear vector error correction (VEC) model proposed by Sims (1990) in examining the selected determinants of economic growth in Malaysia. Secondly, most of the past studies have neglected the role of the economic crisis in influencing the final empirical result between endogenous and exogenous variables. Several past researchers believed that, the impact of education on economic growth will change following the crisis event. Findings from this study will therefore potentially fill the knowledge gap on the role of education in effecting economic growth in the post- economic crisis condition, in both the short and long term.

The rest of the paper is structured as follows: The next section is the literature review followed by the methodology employed in this study. The fourth section provides the empirical results and discussion. The conclusions of the study will be included in the final section of the paper.

\section{LITERATURE REVIEW}

This section will comprise in-depth discussions related to the education-led growth hypothesis together with the relevant literature.

\subsection{The Education- Led Growth Hypothesis}

The issue underlying the education-led economic growth hypothesis is not new. But the issue itself, namely the education-economic growth linkage in the post-crisis period, caught little attention among past researchers. This section presents the in-depth discussions centering on the hypothesis which specifies that education drives economic growth. In other words, the economic growth of a country is stimulated by an increase in government spending on the education sector. The desired effect is the ability to produce more quality human capital for the country, which in turn should lead to increase in national productivity in the long-run. Many past studies on the hypothesis were recorded in the literature covering both developed and developing countries and various aspects were examined including economics, demography, geography and politics. But, there are still knowledge gaps in the economic perspective that need to be addressed. According to Rambeli et al. (2020) for instance, these included verification on the positive role of education on economic growth in Malaysia. Through utilizing the deterministic econometric approach, this study shall examine the education-led growth hypothesis in the case for Malaysia. In addition to education expenditure, this study also explores the role of literacy rate in influencing economic growth in the long term. By adopting the Ordinary Least Square (OLS) approach, the study however found non-significant evidence between literacy rate and economic growth in the country. It is thus established that the level of literacy is not an important indicator in measuring economic performance, since illiteracy in Malaysia has substantially decreased since 
independence in 1957. The result instead indirectly supports the positive role of human capital in stimulating economic growth Malaysia.

This result is consistent with the finding by Appiah (2017), who maintained that education can lead to a higher economic growth through the impact of physical capital. Other empirical studies have also supported this finding on education-driven economic growth. Afzal et al. (2011), Salgur (2013) and Marquez-Ramos and Mourelle (2019) further showed evidence of causality between education spending and economic growth. Moreover, Ismail (1998) and Rambeli et al. (2020) have established that the education sector receives high allocation annually and this exerts positive impact on the Malaysian economy. This study also agrees with Wasti et al. (2017), Ganegodage and Rambaldi (2011) and Islam et al. (2016), in confirming that economic growth and socio-economic performance improvement can be achieved through public spending, specifically in the education and health sectors. However, the literature also indicates insufficient studies that focus on specific time regime such as the period following the world economic crisis in Malaysia. This study will thus take the opportunity to fill the knowledge gap by focusing on testing the education-led growth hypothesis during the post-crisis period.

\subsection{The Relationship between Capital and Economic Growth}

There is substantial coverage on the relationship between capital and economic growth through studies conducted by past researchers. The relationship between these two variables can be negative or positive. The prior study by Romer (1990) has claimed that the capital will affect the economic growth positively. Specifically, Iheanacho (2017) found the relatinship to be positive in the longterm. When capital increases, economic growth should naturally increase. However, in the short term this relationship is negative according to findings by Iheanacho (2017) in parallel with Hashim et al. (2020), Moreno, Liu and Mirza (2019), Meyer and Sanusi (2019), and Masoud and Suleiman (2016). Hashim et al (2020) at the same time maintained that capital is significant in affacting economic growth in the long term. The relationship was found highly significant at the 99 percent level. Masoud and Suleiman (2016) however added that the response of economic growth to capital are both positive and negative depending on the time period studied due to the impact of economic shock. In constrast Topcu et al. (2020) established that capital formation exerts negative impact on low income countries. The impact of gross capital formation thus has varying effects on economic growth being dependant on the income level of the country.

\subsection{The Relationship between Employment and Economic Growth}

Past empirical studies, including Shahid (2014), Rambeli et al. (2016b), Rambeli et al. (2016a) and Hashim et al. (2019), have substantiated the relationship between employment and economic growth. For example, Rambeli et al. (2016b) established that employment was not important in influencing economic growth in Malaysia in the long term. This finding however contradicted Rambeli et al. (2016a) who indicated otherwise. This contradiction between the two models employed was due to different control variables used which included long-term system equations. In addition, the study by Shahid (2014), found dynamic relationship between employment and economic growth. He suggested the exiastance of long-term relationship between the two variables, but in the short term however the effect of employment is negative and significant. These findings are consistent with those of Mujahid and un Zafar (2012) and Sarwar and Abbasi (2013). 


\subsection{The Relationship between Financial variable and Economic Growth}

Financial variables generally attract the attention of researchers keen in evaluating economic growth performance of a country. Hussain and Haque (2017) had stated that money supply exerts important impact on the growth rate of output in the long run. They suggested that government should maintain consistency and follow the Taylor rule in order to allow money supply to increase at a steady rate and keep pace with economic growth. Dingela and Khobai (2017) also revealed significant positive relationship between money supply and economic growth, both in the short and long run. According to Rambeli et al. (2019), broad money and output are moving together in the same direction to develop the long-term equilibrium among the variables in the equation system across different economic situations. The result further suggests that, the broad money plays an important role in driving economic growth in Malaysia under every condition of the economic scenario, across the exchange rate regime. This was proven by the significant result of broad money across the period under investigation. However, Odhiambo (2008) perceived the contribution of financial variables in the case of Kenya's economic growth as ambiguous.

\section{METHODOLOGY}

\subsection{Time Series Data}

This study was conducted using monthly data in Malaysia covering the period from January 2010 to September 2020. The objective was to investigate the impact of government expenditure in education on economic growth in Malaysia. The monthly data sourcing was considered of sufficient frequency for reliable data analysis as compared to quarterly or annual collation. This is consistent with McCleary and McDowall (1984) and Liu et al. (2019) who suggested that more frequent data sourcing will give better model estimation since a large data volume could identify more complete and precise pattern. Further, data of longer periods may provide a complete representation of properties of the time series and ensure better result. Thus, more data is always preferable at the very least, since a time series should be sufficiently long enough to capture the phenomena of interest. Moreover, this study focussed on the recovery period in the aftermath of the world economic crisis. Following Rambeli et al. (2020), the time frame was selected based on the post-crisis scenario from January 2010 to September 2020. Table 1 shows the five widely used macroeconomic variables used in the study, namely industrial production index as a proxy of GDP, gross fixed capital formation, employment, government expenditure in education and broad money supply (M3). The time series data used were obtained from the official website of Bank Negara Malaysia, Kneoma dataset website, and datasets of the Department of Statistic Malaysia (DOSM) and The Global Economics. Due to unit differences between variables, and to avoid problems in model specification, all data were converted to the linear form of natural logarithm. 
Table 1: Time series data sources

\begin{tabular}{|c|c|c|c|}
\hline $\begin{array}{c}\text { Macroeconomics } \\
\text { variables }\end{array}$ & $\begin{array}{c}\text { Name of } \\
\text { variable in } \\
\text { modelling }\end{array}$ & Sources of data & Link of data sources \\
\hline $\begin{array}{l}\text { Industrial Production } \\
\text { Index }\end{array}$ & EG & $\begin{array}{l}\text { Department of } \\
\text { Statistics } \\
\text { Malaysia }\end{array}$ & $\begin{array}{l}\text { https://www.dosm.gov.my/v1/index.php?r=c } \\
\text { olumn/ctimeseries\&menu_id=bnk3bk0wTTk } \\
\text { xOXVHaVg3SUFDMlBUUT09 }\end{array}$ \\
\hline $\begin{array}{l}\text { Gross fixed capital } \\
\text { formation }\end{array}$ & $\mathrm{CFCF}$ & Kneoma & https://knoema.com/ \\
\hline Employment & EMP & $\begin{array}{l}\text { The Global } \\
\text { Economy }\end{array}$ & $\begin{array}{l}\text { https://www.theglobaleconomy.com/Malaysi } \\
\text { a/employed_persons/ }\end{array}$ \\
\hline Education & EDU & $\begin{array}{l}\text { Bank Negara } \\
\text { Malaysia }\end{array}$ & https://www.bnm.gov.my/-/msb-11-2020 \\
\hline $\begin{array}{l}\text { Broad Money Supply } \\
\text { (M3) }\end{array}$ & FIN & $\begin{array}{l}\text { The Global } \\
\text { Economy }\end{array}$ & $\begin{array}{l}\text { https://www.theglobaleconomy.com/Malaysi } \\
\text { a/money_supply/ }\end{array}$ \\
\hline
\end{tabular}

\subsection{Model Specifications}

This study employed the Cobb Douglast production function, basically a nonlinear productivity model, as pioneered by Cobb and Douglas (1928). In the early development phase of the function, Cobb and Douglas believed that a country's productivity can be enhanced by using two main sources, namely capital and labour force. The productivity model maintained that aggregate productivity is influenced by these two variables. Therefore, the following basic model of CobDouglas model will be used;

$$
E G=\alpha C A P^{\beta_{1}} E M P^{\beta_{t}} \ell^{v t}
$$

Nevertheless, many past studies have also maintained that productivity is not only affected by capital and labour but additionally by other macroeconomic factors (Solow, 1957; Abugamea, 2017; Rambeli et al., 2016a). As referenced to Rambeli et al. (2020) the augmented model specificantion proposed in this study is as follows;

$$
E G=\beta_{0} C A P^{\beta_{1}} E{ }^{\beta_{2}} E^{2} U^{\beta_{3}} \operatorname{FIN}^{\beta_{4}} \ell^{v t}
$$

Since equation (2) is a non linear model, parameter values for $\beta_{i}(i=0,1,2,3,4)$ cannot be directly estimated. Therefore, it is suggested that the production function be amended into loglinear model as follows:

$$
\log E G_{t}=\beta_{0}+\beta_{1} \log C A P_{t}+\beta_{2} \log E M P_{t}+\beta_{3} \log E D U_{t}+\beta_{4} \log F I N_{t}+v_{t}
$$

In equation (3), EG represents economic growth data series and represented by Industrial production index (EG). Capital is represented by gross fixed capital formation (CAP). The EMP is employment and EDU represents government expenditure in education. Financial variable is represented by broad money supply under FIN. All data series are in monthly frequency as denoted by $t$, and all values are in natural logarithm. The notation $v_{t}$ is error term, $\beta_{0}$ is constant and $\beta_{i}$ is coefficient or magnitude where $i=1,2,3,4$. 


\subsection{Econometric Approaches}

In general, the study adopted the methodology employed by Rambeli et al. (2019). This section outlines the methodology framework used. Firstly, the univariate unit root test was utilised as proposed by Dickey and Fuller (1979). Secondly, in order to capture the long-term relationship between the variables, the cointegration test procedure was adopted as recommended by Johansen and Juselius (1990). Lastly, this chapter expanded on the analysis through utilizing the Granger causality tests in VECM in accordance with Sims (1972).

\subsubsection{Augmented Dickey Fuller Tests}

The unit root test is a formal preparation test before proceeding to the cointegration test. In order to test for presence or absence of unit root we employed the Augmented Dickey Fuller (ADF) test as proposed by Dickey and Fuller (1979). The ADF unit root test was an extension of the Dickey Fuller (DF) unit root test proposed earlier by Dickey (1976). Based on previous readings, Gujarati (2004; p. 817) noted that, in conducting the DF test, we assume that the error term $\left(U_{t}\right)$ is uncorrelated. In cases where $U_{t}$ is correlated, Dickey and Fuller (1979) have developed the ADF unit root test. This well-known test adopts a parametric autoregression to approximate the Autoregressive Moving Average (ARMA) structure of the errors in the test regression. The ADF test structure is given below. Consider a simple general AR $(p)$ process given by the equation;

$$
e_{t}=\alpha+\beta_{1} e_{t-1}+\beta_{2} e_{t-2}+\ldots .+\beta_{i} e_{t-i}+v_{t}
$$

If this is the process generating the data and an AR (1) model is fitted, say

$$
e_{t}=\alpha+\beta_{1} e_{t-1}+\varepsilon_{t}
$$

Then,

$$
\varepsilon_{t}=\beta_{2} e_{t-1}+\ldots .+\beta_{i} e_{t-i}+v_{t}
$$

Here, the autocorrelations of $\varepsilon_{t}$ and $\varepsilon_{t-k}$ for $\mathrm{k}>1$, will be non-zero, because of the presence of the lagged ' $\mathrm{e}$ ' terms. Thus, an indication of whether it is appropriate to fit an AR (1) model or otherwise can be aided by considering the autocorrelations of the residual from the fitted models. The specific sttucture of AR(1) process is explained further in Dickey and Fuller (1981). To illustrate how the DF test can be extended to autoregressive processes of order greater than 1 , consider the simple AR (2) process below.

$$
e_{t}=\alpha+\beta_{1} e_{t-1}+\beta_{2} e_{t-2}+v_{t}
$$

Note that this is the same as:

$$
e_{t}=\alpha+\left(\beta_{1}+\beta_{2}\right) e_{t-1}-\beta_{2}\left(e_{t-1}-e_{t-2}\right)+v_{t}
$$


And subtracting $g_{t-1}$ from both sides gives:

$$
\Delta e_{t}=\delta_{1}+\delta_{2} e_{t-1}+\delta_{3} e_{t-1}+v_{t}
$$

Where the following equation has been defined:

$$
e_{t}=\beta_{1}+\beta_{2}-1
$$

And,

$$
\delta_{1}=1 \beta_{2}
$$

Therefore to perform a Unit Root test on an AR (p) model the following regression should be estimated:

$$
\Delta e_{t}=\delta_{1}+\delta_{2} e_{t-1}-\sum_{j=1}^{p} \delta_{i} \Delta e_{t-i}+v_{t}
$$

The Standard Dickey-Fuller model has been 'augmented' by $\Delta \varepsilon_{t-i}$. In this case the regression model and the ' $t$ ' test are referred as the ADF unit root test. In equation (12) above, $\Delta e_{t}$ is a set of variables under observation including, government expenditure in education, capital, employment and financial variable. And, $\Delta$ is differencing operator, $t$ indicates a time series data, whereas $v_{t}$ is the white noise residual of zero mean and a constant variance. The set of parameters to be estimated includes, $\delta_{1}, \delta_{2}, \theta_{i, \ldots}, \theta_{m}$. Both the null and alternative hypotheses in unit root tests are as follows:

Hypothesis null:

$$
H_{0^{*}} \delta=0 \text { ( } \mathrm{e}_{\mathrm{t}} \text { is non-stationary / a unit root process) }
$$

Hypothesis alternative:

$$
H_{0 .} \delta \neq 0 \text { (e is stationary) }
$$

The unit root hypothesis of the ADF can be rejected if the t-test statistic from these tests is negative and less than the critical value tabulated. In other words, through the ADF test, a unit root exists in the series e (implies non-stationary) if the null hypothesis of delta equal zero is not rejected (Gujarati, 2004).

\subsubsection{Johansen Juselius Cointegration Tests}


After employing the ADF unit root testing (Dickey \& Fuller, 1979), the next procedure is to find the long term co-integrating vector. The study subsequently employs the Johansen Juselius cointegration testing (Johansen \& Juselius, 1990). This cointegration method is one of the powerful approaches in finding the co-integrating vector in the equation (Johansen, 1988). The method is additionally capable of producing a more robust estimator compared to other methods such as Engle Granger's method of combining (Gonzalo, 1994). The Johansen method contains two likelihood ratio statistics to test the existence of a co-integration vector, Trace test $\left(\lambda_{\text {trace }}\right)$ and maximum test $\left(\lambda_{\max }\right)$ are based on following formula:

$$
\begin{gathered}
\lambda_{\text {trace }}=-T \sum_{i=r+t}^{n} \ln \left(1-\lambda_{i}\right) \\
\lambda_{\text {mas }}\left(r_{s} r+1\right)=-T \ln \left(1-\lambda_{r+1}\right)
\end{gathered}
$$

Where, $\mathrm{t}$ is number of observations used and Lambda $(\boldsymbol{\lambda})$ is Eigen values.

The result of these two statistical values will be compared with the critical values available from the tables provided by Osterwald-Lenum (1992). Co-integration can be defined as a form of long-run balance or joint movement between sets of time series data in a system. However, in the short run, variables may be scattered from each other and cause imbalances in the system. The error correction model (ECM) measures the extent to which the system is out of balance in the short run (Rambeli \& Podivinsky, 2013; Asmah, 2013).

\subsubsection{Vector Error Correction Model (VECM)}

Next is the procedure to develop the VECM for short-run relationship testing. In this case, the Granger causality test will be conducted in the VECM framework. Granger causality can be defined as the relationship between the variables in the short run. According to Granger (1969), variable $\mathrm{Y}$ is said to be Granger to variable $\mathrm{X}$, if $\mathrm{Y}$ information is significant in making the forecasting on the value of $\mathrm{X}$. If both $\mathrm{X}$ and $\mathrm{Y}$ is stationary at the first difference level, then that is the co-integration on the degree of integration. The period of error correction should then be included in the model before the Granger cause test can be conducted. The existence of an error correction term (ECT) describes any movement in the dependent variable. It is actually an imbalance function in the co-integration relationship (as described by ECT) and this is also similar to other independent variables (Engle \& Granger, 1987). According to Engle and Granger (1987) and Todo and Phillips (1993), failure to estimate the error correction factor will produce incorrect results in the tests conducted. In other words, the ECT in VECM forged another method to enhance the accuracy of the Granger causality test. Therefore, if all the variables involved in this study are stationary at first difference level then the error of long-term relationship regression may be used to estimate VECM as shown below. (Note that the symbol $\Delta$ in the equation represents the first difference level for each variable involved in the study): 
$\Delta \log I P I_{t}=\alpha_{1}+\sum_{i=1}^{n} \alpha_{i} \Delta \log I P I_{t-i}+\sum_{t=1}^{n} \beta_{i} \log C A P_{t-i}+\sum_{t=1}^{n} \theta_{i} \log E M P_{t-1}+\sum_{t=1}^{n} \delta_{i} \Delta \log E D U_{t-i}$

$+\sum_{t=1}^{n} \phi_{i} \Delta \log F I N_{t-i}+\gamma_{1} E C T_{t-1}+v_{2}$

$\Delta \log C A P_{t}=\alpha_{2}+\sum_{i=1}^{n} \alpha_{i} \Delta \log I P I_{t-i}+\sum_{t=1}^{n} \beta_{i} \log C A P_{t-i}+\sum_{t=1}^{n} \theta_{i} \log E M P_{t-1}+\sum_{t=1}^{n} \delta_{i} \Delta \log E D U_{t-i}$

$+\sum_{t=1}^{n} \phi_{i} \Delta \log \operatorname{FIN}_{t-i}+\gamma_{1} E C T_{t-1}++v_{3}$

$\Delta \log E M P_{t}=\alpha_{3}+\sum_{i=1}^{n} \alpha_{i} \Delta \log I P I_{t-i}+\sum_{t=1}^{n} \beta_{i} \log C A P_{t-i}+\sum_{t=1}^{n} \theta_{i} \log E M P_{t-1}+\sum_{t=1}^{n} \delta_{i} \Delta \log E D U_{t-i}$

$+\sum_{t=1}^{n} \phi_{i} \Delta \log F I N_{t-i}+\gamma_{1} E C T_{t-1}+v_{4}$

$\Delta \log E D U_{t}=\alpha_{4}+\sum_{i=1}^{n} \alpha_{i} \Delta \log I P I_{t-i}+\sum_{t=1}^{n} \beta_{i} \log C A P_{t-i}+\sum_{t=1}^{n} \theta_{i} \log E M P_{t-1}+\sum_{t=1}^{n} \delta_{i} \Delta \log E D U_{t-i}$

$+\sum_{t=1}^{n} \phi_{i} \Delta \log F I N_{t-i}+\gamma_{1} E C T_{t-1}+v_{5}$

$\Delta \log$ FIN $_{t}=\alpha_{5}+\sum_{i=1}^{n} \alpha_{i} \Delta \log I P I_{t-i}+\sum_{t=1}^{n} \beta_{i} \log C A P_{t-i}+\sum_{t=1}^{n} \theta_{i} \log E M P_{t-1}+\sum_{t=1}^{n} \delta_{i} \Delta \log E D U_{t-i}$

$+\sum_{t=1}^{n} \phi_{i} \Delta \log F I N_{t-i}+\gamma_{1} E C T_{t-1} v_{6}$

From equations (15) to (19), the notation $\sum$ symbolizes the optimum lag selection for each variable in the dynamic modeling. In this study, the Akaike Information Criterion (AIC) in vector autoregression (VAR) is utilized in order to select the optimum lag length for each variable in the equation system (Guttierrez, 2007). Additionally, the notations $\alpha_{1}$ to $\alpha_{6}$ are denoted as constants. In each system of the dynamic equation, the ECT has been developed. The notation $v_{t x}$ represents the white noise of each dynamic system.

\subsubsection{Diagnostic and Stability tests}

To prevent the model from parameter bias, being ineffective, and having error in the estimated model it should have a normal distribution, a constant mean of zero value and variance, no autocorrelation or homoscedasticity, and no multicollinerity (Bekhet \& Othman, 2018). To verify this, the ARCH test, Breusch- Godfrey LM test, Jarque-Bera test are conducted.

\section{RESULTS AND DISCUSSION}

\subsection{Augmented Dickey Fuller Unit Root Test}


To achieve the study objective this investigation needs the same stationary level for each set of data involved as variables. The ADF unit root test was adopted as examination procedure. This has become a pre-condition in implementation of co-integration analysis and granger causality in the VECM framework. The statistic value of the ADF will be compared with critical values generated by result estimation. Results of the ADF unit root tests, both at the level and at first differencing are reported in Table 2 taking into consideration a few types of autoregressive (AR) model including none, time trend and without time trend variable in the regression. Some significant results are recorded. The results indicate that some of the series are stationary and others non-stationary at their level form. The tests are thus continued at the first differencing stages. The subsequent results indicate that all the series are stationary at their first difference form. When the ADF test is conducted at the first difference of each variable, all variables are easily rejected at $99 \%$ significance levels as shown in Table 2.

Table 2: The Result of Augmented Dickey Fuller (ADF) of Unit Root Test

\begin{tabular}{|c|c|c|c|c|c|c|}
\hline \multirow[t]{2}{*}{ Variables } & \multicolumn{3}{|c|}{ At Level } & \multicolumn{3}{|c|}{ At First Difference } \\
\hline & None & $\begin{array}{c}\text { Without } \\
\text { Trend }\end{array}$ & With Trend & None & $\begin{array}{c}\text { Without } \\
\text { Trend }\end{array}$ & With Trend \\
\hline $\log E G$ & $\begin{array}{l}0.494345[9] \\
(0.8207)\end{array}$ & $\begin{array}{l}-1.628881 \\
{[9]} \\
(0.4647)\end{array}$ & $\begin{array}{l}0.804311[9] \\
(0.9997)\end{array}$ & $\begin{array}{l}-5.172065 \\
{[9]} \\
(0.0000) * * *\end{array}$ & $\begin{array}{l}-5.181331[9] \\
(0.0000)^{* * *}\end{array}$ & $\begin{array}{l}-5.532630[9] \\
(0.0001)^{* * * *}\end{array}$ \\
\hline $\log C A P$ & $\begin{array}{l}0.266974[9] \\
(0.7619)\end{array}$ & $\begin{array}{l}-1.490159 \\
{[9]} \\
(0.2098)\end{array}$ & $\begin{array}{l}-1.777997 \\
{[8]} \\
(0.2208)\end{array}$ & $\begin{array}{l}-12.71050[9] \\
(0.0000) * * *\end{array}$ & $\begin{array}{l}-12.72726[8] \\
(0.0000)^{* * *}\end{array}$ & $\begin{array}{l}-12.74959 \\
{[9]} \\
(0.0000)^{* * *}\end{array}$ \\
\hline $\log \mathrm{EMP}$ & $\begin{array}{l}2.248718 \text { [9] } \\
(0.9941)\end{array}$ & $\begin{array}{l}-1.647006 \\
{[9]} \\
(0.4555)\end{array}$ & $\begin{array}{l}-1.469132 \\
{[9]} \\
(0.8348)\end{array}$ & $\begin{array}{l}-2.588661[9] \\
(0.0099) * * *\end{array}$ & $\begin{array}{l}-4.946324[7] \\
(0.0001)^{* * *}\end{array}$ & $\begin{array}{l}-4.542735[9] \\
(0.0020)^{* * *}\end{array}$ \\
\hline $\log \mathrm{EDU}$ & $\begin{array}{l}-0.785332 \\
{[9]} \\
(0.3740)\end{array}$ & $\begin{array}{l}-2.290661 \\
{[8]} \\
(0.1767)\end{array}$ & $\begin{array}{l}-1.571187 \\
{[9]} \\
(0.7986)\end{array}$ & $\begin{array}{l}-9.301535[9] \\
(0.0000)^{* * *}\end{array}$ & $\begin{array}{l}-9.306141[9] \\
(0.0000)^{* * * *}\end{array}$ & $\begin{array}{l}-9.649697[9] \\
(0.0000)^{* * *}\end{array}$ \\
\hline $\log \mathrm{FIN}$ & $\begin{array}{l}-1.771362 \\
{[8]} \\
(0.721)\end{array}$ & $\begin{array}{l}-2.464156 \\
{[9]} \\
(0.1267)\end{array}$ & $\begin{array}{l}-1.617296 \\
{[8]} \\
(0.7809)\end{array}$ & $\begin{array}{l}-2.873624[3] \\
(0.0043)^{* * *}\end{array}$ & $\begin{array}{l}-11.36092[9] \\
(0.0000)^{* * *}\end{array}$ & $\begin{array}{l}-11.81652[9] \\
(0.0000)^{* * *}\end{array}$ \\
\hline
\end{tabular}

Note: Numbers in [] are numbers of lag that follow Akaike Info Criterion (AIC). The () are numbers of prob.* of Augmented Dickey Fuller Test Statistic. The sign '***', '**', and '*' specify significance at $99 \%$, 95\%, and $90 \%$ significance levels respectively.

Table 3: The recorder value of AIC in Vector Auto Regression (VAR) Model.

\begin{tabular}{cc}
\hline \hline Lag Length & Akaike Information Criterion (Aic) \\
\hline 7 & -23.43855 \\
8 & -23.36263 \\
9 & -23.58963 \\
10 & -23.57070 \\
11 & -23.82219 \\
12 & $-24.09221^{*}$ \\
\hline \hline
\end{tabular}


Table 4: The Result of Johansen Co-integration System

\begin{tabular}{lllccccc}
\hline \hline \multicolumn{2}{l}{ Hypothesis } & & \multicolumn{5}{c}{ Co-integrating System } \\
\hline$H_{0}$ & $\boldsymbol{H}_{1}$ & Trace Statistics & $\begin{array}{c}5 \% \\
\text { Critical } \\
\text { Value }\end{array}$ & $\begin{array}{c}1 \% \\
\text { Critical } \\
\text { Value }\end{array}$ & $\begin{array}{c}\text { Max } \\
\text { Eigenvalue }\end{array}$ & $\begin{array}{c}5 \% \text { Critical } \\
\text { Value }\end{array}$ & $\begin{array}{c}1 \% \\
\text { Critical } \\
\text { Value }\end{array}$ \\
\hline $\mathrm{r}=0$ & $\mathrm{r}>0$ & $103.8458^{*}(* *)$ & 68.52 & 76.07 & $42.70687 *(* *)$ & 33.46 & 38.77 \\
$\mathrm{r}<1$ & $\mathrm{r}>1$ & $61.13889 *(* *)$ & 47.21 & 54.46 & $34.56397 *(* *)$ & 27.07 & 32.24 \\
$\mathrm{r}<2$ & $\mathrm{r}>2$ & 26.57493 & 29.68 & 35.65 & 15.84808 & 20.97 & 25.52 \\
$\mathrm{r}<3$ & $\mathrm{r}>3$ & 10.72685 & 15.41 & 20.04 & 9.011366 & 14.07 & 18.63 \\
$\mathrm{r}<4$ & $\mathrm{r}>4$ & 1.715484 & 3.76 & 6.65 & 1.715484 & 3.76 & 6.65 \\
\hline \hline
\end{tabular}

Note: Critical values is obtained from Osterwald-Lenum (1992). Sign (**) indicates rejected critical values at significant level of $5 \%$ and $(*)$ at $1 \%$.

For example, at level form in none autoregressive model, the data series broad money supply (FIN) is not significant at 90 percent level, with the statistic value at -1.771362 (lag selection at 8). However, at first difference form, at none autoregressive model, FIN is stationary at 99 percent significance. The next test is to identify the optimum lag length for the Johansen Juselius cointegration. The optimum lag can be identified by using the VAR. In this study, the optimum lag length is estimated at between lag 2 to lag 12 in order to compare the minimum value of AIC. In other words, the minimum value across lag 7 until lag 12 is the optimum lag for the Johansan Juselius cointegration test. The same optimum lag in VAR, will be used in developing ECM and VECM. Table 3 simplifies the estimation of unrestricted VAR, with the default lag length of 7 to 12. According to Table 3, the optimum lag length as suggested by VAR is at lag 12 .

The Johansen Juselius cointegration test is reported in Table 4. The cointegration is tested to examine long-run relationship between the dependent variables and independent variables. If the series are cointegrated, then the corresponding error correction term and an error correction model must be obligatory. The number of cointegration vectors is determined by two likelihood ratio tests, namely maximum eigenvalue and trace eigenvalue statistics. The critical values for each test are from Osterwald-Lenum (1992) statistic table. Through the analysis of Johansen Juselius cointegation, the results suggest at one of two cointegrating vectors in the equation system in the long run. Therefore, following the method proposed by Johansen and Juselius (1990), when cointegrating vectors are found, it is important to develop an error correction terms in the VECM.

In Table 4, the results of cointegration at trace statistic and maximum statistic values are explained. The trace statistics obviously demonstrate that the null hypothesis of $\mathrm{r}=0$, is easily rejected at 0.01 and 0.05 significant levels. The computed value 103.8458 is obviously larger than the critical values at 0.05 and 0.01 levels, mainly 68.52 and 76.07 , respectively. Next, the null hypothesis of $r<1$ is accepted at the 0.01 and 0.05 significant levels. The computed value 61.13889 is obviously larger than the critical values at 0.05 and 0.01 , these being 47.21 and 54.46 respectively. The same goes for the result of maximum eigen value which obviously demonstrates that the null hypothesis $r<1$, is also easily rejected at 0.01 and 0.05 significant levels. The computed value is 42.70687 , larger than the critical value of 0.05 and 0.01 which is 33.46 and 38.77 respectively. Secondly, the same goes for the result of maximum eigen value which shows that $r<1$, which is easily rejected at 0.01 and 0.05 significant levels. The computed value is 34.56397 larger than its critical value of 0.05 and 0.01 which is 27.07 and also 32.24 
respectively. In other words, the series in the system are moving together but cannot be separated far from each other; from the short-term disequilibrium towards long-term equilibrium.

Next, the study executed the granger causality in VECM framework in order to identify the shortrun and long-run causality or temporal link between the variables in this study. Moreover, in the VECM there are the error correction term (ECT). The term measures the speed of adjustment of any short-term disequilibrium towards long-run equilibrium in the long term. The ECT must be negative with magnitude values between -1 and 0 . The negative signage of ECT is required to ensure the model converges to the steady state, otherwise it would be divergent. The result in Table 5, suggests that there exist long-run equilibrium among variables in the equation system. This finding is consistent with those of Rahman (2011), Afzal et al. (2010), Eggoh et al. (2015), and Kangjuan et al. (2017). The result is additionally supported by the negative sign in the $\mathrm{ECT}_{\mathrm{t}}$ 1. For example, based on economic growth model, the ECT magnitude value is -1.0241 . By implication, the short-run disequilibrium will require around more than a year ( $>12$ months) in order to get back into long-run equilibrium. All estimated systems also passed the diagnostic analysis as explained in the methodology section as shown in Table 6. In addition, Table 5 simplifies the granger causality direction as shown in Table 6. Based on the tables, the result suggests bidirectional causality, from education spending to economic growth, and vice versa. In other words, not only education expenditure granger cause economic growth in the short run but the economic growth conversely granger cause the education expenditure. The result also suggests for unidirectional relationship from financial to education spending in Malaysia.

Table 5: Summarize of overall Temporal Granger Causality test

\begin{tabular}{cccc}
\hline \hline $\begin{array}{l}\text { Number of } \\
\text { Directions }\end{array}$ & Unrecovered Regime (Direction of Causality) & Wald test & p-value \\
\hline 1 & Growth Granger-cause Education & {$[2.5341]$} & $(0.043)^{* *}$ \\
& Education Granger-cause Growth & {$[2.543]$} & $(0.032)^{* *}$ \\
& Growth Granger-cause Capital & {$[2.7286]$} & $(0.072)^{*}$ \\
2 & Capital Granger-cause Growth & {$[2.321]$} & $(0.072)^{*}$ \\
& Growth Granger-cause Employment & {$[3.741]$} & $(0.032)^{* * *}$ \\
& Employment Granger-cause Growth & {$[3.752]$} & $(0.045)^{* *}$ \\
& Growth Granger-cause Financial & {$[3.732]$} & $(0.052)^{* *}$ \\
& & & $(0.089)^{*}$ \\
\hline \hline
\end{tabular}

Note: Asterisks $(* * * *),(* *)$ and $(*)$ indicates statistically significant at $1 \%, 10 \%$ and $30 \%$ level, respectively. 
Rosilawati Amiruddin, Ismadi Ismail

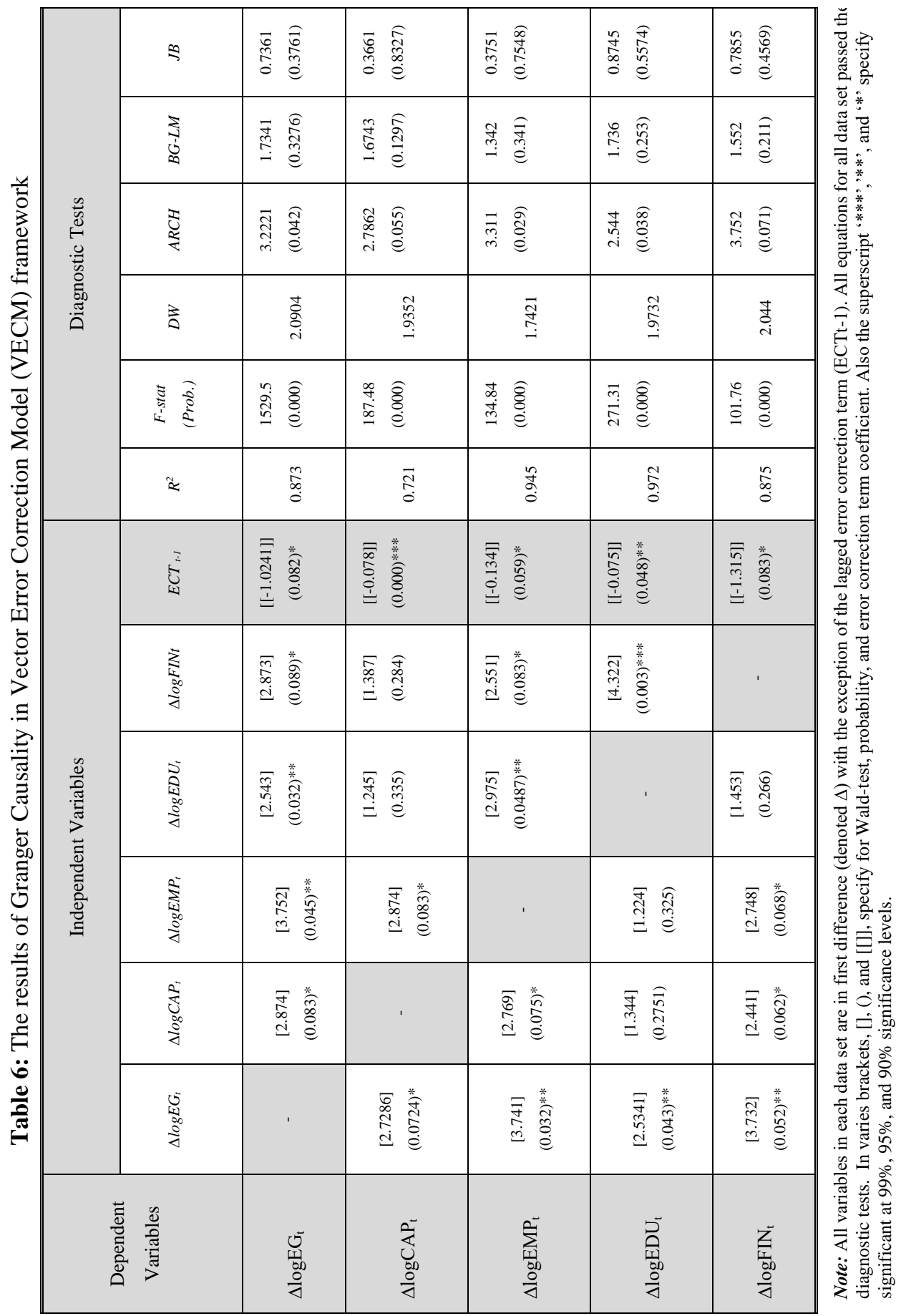




\section{DISCUSSIONS AND IMPLICATIONS}

Results of this study as presented in the previous section have validated the education led-growth hypothesis for Malaysia as applied to the recovery regime following the economic crisis in 2008. By adopting the time series VEC model, the study also confirms that the hypothesis holds true in the short and long run for the estimated modelling. This finding is, consistent with previous findings for long-run relationship, including Kakar et al. (2011), Rambeli et al. (2020), Rahman (2011), Sunde (2017) and Wasti et al. (2017). In iddition, there are some studies that also support short-run relationships between government expenditure in education and economic growt, such as Rahman (2011), Sunde (2017) and Wasti et al. (2017). Collectively they are all consistent with the idea that, an increase in government expenditure in education will directly elevate the economic growth of the country. In other words, the education sector is a driver to the country's economic growth in the long and short term. Hence, when the government raises allocation to the education sector during the recovery period, economic growth will be enhanced. This will in turn lead the government into more spending into education as compared to that of the previous year. This benign effect on education will enable the country to produce more skilled human capital that should better serve towards elevating productivity. The hypothesis thus shows that the economic injury inflicted during the crisis can be mitigated towards enhancing economic growth.

Some empirical findings in the study, on long-run relationships between government expenditure in education and economic growth, are however found contradictory with those of some studies including Jajri and Ismail (2012), Marquez-Ramos and Mourelle (2019) and Eggoh et al. (2015). A few researchers in the past, including Kakar et al. (2011) and Jajri and Ismail (2012), were against short-run relationships between government expenditure in education in relation to economic growth. According to Idris Jajri and Ismail (2012), the failure in government spending is because the allocation provided is not spent at an optimal level by the states. This has subsequently slowed down the process of producing human capital and thus with adverse consequence on the economy. Results of this study further indicate that the traditional inputs of capital and labour are statistically significant in both the long and the short run, exerting positive effects on economic growth in Malaysia thus supporting the model by Cobb and Douglas (1928). Malaysia's economic growth is basically input-driven, i.e. by adding increasing quantity of resources into the same production function will produce greater productivity. The financial variables played by broad money supply further shows their important role in influencing economic growth for both, short and long run in Malaysia during the post-crisis recovery period.

\section{CONCLUSIONS}

This study specifically aim to investigate the role of selected macroeconomic variables, namely capital, employment, government expenditure in education and financial, on economic growth in Malaysia through utilising the vector error correction model. The monthly time series data were used spanning January 2010 to September 2020. Through using the vector error correction model, the study established that the education-led growth hypothesis was supported in Malaysia during the recovery regime in the aftermath of the world economic crisis of 2008. From the policy perspective, it is suggested that the Malaysian government should continue to support the increase in education sector spending, since the study has proven that this effort should lead to 
increase in economic growth in both the short and long run. Moreover, the enhanced spending should indirectly produce positive impact on human capital development through increasing student admissions at the tertiary level. Additionally, it should also provide greater opportunity for the government to expand research and development so as to enhance the education platform in the country. For instance, through increased budget in education, the government will be able to provide better facilities on education (such as better E-learning platform or smart class room) in schools and universities. Most of the variables investigated in the study produced results as anticipated. The study also validated the role played by capital and employment in relation to economic growth in the post-crisis period. By 2010, since the 2008 crisis, economic development commenced under self-remedy based on the strength of capital and labour resources which together provided positive solution to the economy. Financial development additionally serves as saviour to the Malaysian economy. The study thus concludes that financial policy plays a crucial role in improving education for the country in the long term. Financial development is seen as the main catalyst in fostering sustainable development in the future although most of the other variables examined displayed encouraging impacts on Malaysia's economic growth. By implication, the study reveals that financial planning as related to the national education policies must be carefully and meticulously conducted to ensure future success. This is predicated to investment in human capital that essentially includes adequate education expenditure at different levels that is crucially important in national long-term planning. Specific financial planning for human capital development is therefore very important to ensure that the expenditure incurred is optimally utilised leading eventually to sustainable development in Malaysia on the long term. For future enquiries, the model used in this study, including the Autoregressive distributed lag (ARDL) bounds test model, should also be applied to selected ASEAN countries.

\section{ACKNOWLEDGMENT}

This research is funded by University Grants (GPUP) (Code: 2019-0072-107-01) awarded by Universiti Pendidikan Sultan Idris (UPSI), Tanjong Malim, Perak.

\section{REFERENCES}

Abdullah, M. K. L., Mohd Ali, A., Abd Wahid, H., \& Salleh Hudin, N. (2020). Integrated Model of The Implementation of Pedagogical Skills in Teaching and Learning of the 21st century among lecturers of Universiti Pendidikan Sultan Idris. Management Research Journal, 9, 36-42.

Abugamea, G. (2017). The Impact Of Education On Economic Growth In Palestine: 1990-2014 (MPRA Paper No. 89749). Germany: University of Munich.

Afzal, M., Rehman, H. U., M. S., \& Sarwar, K. (2011). Education And Economic Growth In Pakistan: A Cointegration And Causality Analysis. International Journal Of Educational Research, 50(5-6), 321-335.

Afzal, M., Farooq, M. S., Ahmad, H. K., Begum, I., \& Quddus, M. A. (2010). Relationship Between School Education And Economic Growth In Pakistan. Pakistan Economic And Social Review, Vol. 48(1), 39-60. 
Appiah, E. N. (2017). The Effect Of Education Expenditure On Per Capita GDP In Developing Countries. International Journal Of Economics And Finance, 9 (10), 136-144.

Asmah, E. E. (2013). Sources of Real Exchange Rate Fluctuations in Ghana. America Journal of Economics, 3(6), 291-302.

Bamigboye, G., Ede, A., \& Adeyemi, G. (2016). Impact of Economic Crisis on Education: Case Study of Southwest Nigeria. Proceedings of INTED2016 Conference. 7th-9th March 2016, Valencia, Spain. ISBN: 978-84-608-5617-7.

Barakat, B., Holler, J., Prettner, K., \& Schuster, J. (2010). The impact of the economic crisis on labour and education in Europe (Vienna Institute of Demography Working Papers No. 6/2010). Vienna: Institute of Demography (VID).

Bekhet, H. A., \& Othman, N. S. B. (2018). The Role of Renewable Energy to Validate Dynamic Interaction between CO2 Emissions and GDP Towards Sustainable Development in Malaysia. Energy Economic, 72, 47-61.

Cobb, C. W., \& Douglas, P. H. (1928). A Theory of Production. American Economic Review, 18, 139-165. https://www.aeaweb.org/aer/top20/18.1.139-165.pdf

Dickey, D. A. (1976). Estimation and Hypothesis Testing for Non-stationary Time Series [Unpublished Doctoral Dissertation]. Iowa State University.

Dickey, D. A., \& Fuller, D. A. (1979). Distributions of the Estimators for Autoregressive Time

Series with a Unit Roots. Journal of American Statistical Association, 74, 427-431.

Dickey, D. A., \& Fuller. W. A. (1981). Likelihood Ratio Statistics for Autoregressive Time Series with a Unit Root. Econometrica, 49(4), 1057-1072.

Dingela, S., \& Khobai, H. (2017). Dynamic Impact of Money Supply On Economic Growth in South Africa. An ARDL Approach (MPRA Paper No. 82539). Germany: University of Munich.

Eggoh, J., Houeninvo, H., \& Sossou, G.-A. (2015). Education, Health And Economic Growth. Journal Of Economic Development, 40(1), 93.

Engle, F. R., \& Granger., C. W. J. (1987). Co-integration and Error Correction: Representation, Estimation, and Testing. Econometrica, 55(2), 251-276.

Frank, N. (2018). Making The Grade: The Contribution Of Education Expenditure To Economic Growth. Undergraduate Economic Review, 14(1), 1-15.

Gonzalo, J. (1994). Five Alternative Methods of Estimating Long-Run Equilibrium Relationships. Journal of Econometrics, 60(1-2), 203-233.

Gujarati, D. (2004). Basic Econometrics. McGrawHill.

Ganegodage, K. R., \& Rambaldi, A. N. (2011). The Impact Of Education Investment On Sri Lankan Economic Growth. Economics Of Education Review, 30(6), 1491-1502.

Granger, C. W. J. (1969). Investigating causal relations by econometric models and cross spectral methods. Econometrica, 40, 424-438.

Guttierrez, C. E. (2007). Selection Of Optimal Lag Length In Cointegrated VAR Models With Weak Form Of Common Cyclical Features (Working Paper Series No. 139). MPRA Paper 66065, University Library of Munich, Germany, revised 2009

Han, J.-S., \& Lee, J.-W. (2019). Demographic Change, Human Capital, And Economic Growth In Korea. Japan \& The World Economy, 53, 100984.

Hanif, N., \& Arshed, N. (2016). Relationship Between School Education And Economic Growth: SAARC Countries. International Journal Of Economics And Financial Issues, 6(1), 294-300. 
Hashim, E., Rambeli, N., Hashim, A., Jalil, N. A., Aziz, S. N., \& Karim, A. H. (2019). Dynamic Relationship Between Real Export, Real Import, Real Exchange Rate, Labor Force And Real Gross Domestic Product In Malaysia. Research In World Economy, 10(5), 20-29.

Hashim, E., Rambeli, N., Abdullah Al- Hadi, A., Hashim, A., \& Mahat, N. I., (2020). Reexamine the Impacts of Education Expenditure, Capital Formation, Human Capital and Expert Labor on Malaysian Economic Growth. Psychology and Education, 57(8), 897-904.

Heyneman, S. P. (1990). Economic Crisis and The Quality of Education. International Journal. Educational Development, 10(2/3), 115-129.

Hussain, M. E., \& Haque, M. (2017). Empirical Analysis Of The Relationship Between Money Supply And Per Capita GDP Growth Rate In Bangladesh. Journal Of Advance In Economics And Finance, 2(1), 54-66.

Idrees, A. S., \& Siddiqi, M. W. (2013). Does Public Education Expenditure Cause Economic Growth? Comparison Of Developed And Developing Countries. Pakistan Journal Of Commerce And Social Sciences, 7(1), 174-183.

Iheanacho, E. (2017). Long-Run Dynamics Of Economic Growth, Gross Fixed Capital Formation And Financial Sector Development: An ARDL Analysis. Journal Of Finance, Banking And Investment, 4(1), 197-213.

Islam, R., Ghani, A. B., Kusuma, B., \& Theseira, B. B. (2016). Education And Human Capital Effect On Malaysian Economic Growth. International Journal Of Economics And Financial Issues, 6(4), 1722-1728.

Ismail, R. (1998). Sumbangan Pendidikan Kepada Pertumbuhan Ekonomi Malaysia, 1970-1996. Jurnal Ekonomi Malaysia, 32, 3-20.

Jajri, I., \& Ismail, R. (2012). An Analysis of Relationship Between Human Capital and Economic Growth. Life Science Journal, 9(4), 3735-3742.

Johansen, S. (1988). Statistical Analysis of Cointegration Vectors. Journal of Economic Dynamics and Control, 12, 231-254.

Johansen, S., \& Juselius, K. (1990). Maximum Likelihood Estimation and Inference on Cointegration with Application to the Demand for Money. Oxford Bulletin of Economics and Statistics, 52, 169-210.

Kakar, Z. K., Khilji, B. A., \& Khan, M. J. (2011) Relationship between Education and Economic Growth in Pakistan: A time series analysis. Journal of International Academic Research, 11(1), 27-32.

Kangjuan, L.V, Yu, Gong, S., Wu, M., \& Xu, X. (2017). Impacts Of Educational Factors On Economic Growth In Regions Of China: A Spatial Econometric Approach. Technological And Economic Development Of Economy, 23(6), 827-847.

Kouton, J. (2018). Education Expenditure And Economic Growth: Some Empirical Evidence From Côte d'Ivoire. Journal of Economic and Sustainable Development, 14(9), 22-34.

Liu, M.-H., Margaritis, D., \& Zhang, Y. (2019). The Global Financial Crisis and the Export-Led Economic Growth in China. The Chinese Economy, 52(3), 232-248.

Mallick, L., \& Dash, D. P. (2015). Does Expenditure On Education Affect Economic Growth In India? Evidence From Cointegration. Theoretical And Applied Economics, 22(4), 63-74.

Mallick, L., Das, P. K., \& Pradhan, K. C. (2016). Impact Of Educational Expenditure On Economic Growth In Major Asian Countries: Evidence From Econometric Analysis. Theoretical And Applied Economics, 23(2), 173-186.

Marquez-Ramos, L., \& Mourelle, E. (2019). Education and economic growth: an empirical analysis of nonlinearities. Applied Economic Analysis, 27(79), 21-45. 
Masoud, A. M., \& Suleiman, N. N. (2016). The Relationship Among Export, Import, Capital Formation And Economic Growth In Malaysia. Journal Of Global Economics, 4(2), 186.

McCleary, R., \& McDowall, D. (1984). A Time Series Approach to Causal Modelling: Swedish Population Growth, 1750-1849. Political Methodology, 10(3), 357-375.

Mercan, M., \& Sezer, S. (2014). The Effect Of Education Expenditure On Economic Growth: The Case Of Turkey. Procedia-Social And Behavioral Sciences, 109, 925-930.

Meyer, D. F., \& Sanusi, K. A. (2019). A Causality Analysis Of The Relationships Between Gross Fixed Capital Formation, Economic Growth And Employment In South Africa.Studia Universitatis Babe-Bolyai Oeconomica, 64(1), 33-44.

Mohamed Noor, N. F., Zakariya. Z., Rambeli, N., \& Abdul Razak, A. (2016). Eksternaliti Modal Manusia Rakan Sekerja Dan Upah Individu: Bukti Empirik Di Sektor Perkhidmatan Di Malaysia. Management Research Journal (MRJ), 6(1), 51-69.

Moreno, G., Liu, H., \& Mirza, N. (2019). Capital Formation, Manufacturing Productivity, Government Consumption And Economic Growth In Colombia: An ARDL Bound Testing Approach. North American Academic Research, 2(3), 1-9.

Mujahid, N., \& uz Zafar, N. (2012). Economic Growth-Female Labour Force Participation Nexus: An Empirical Evidence for Pakistan. The Pakistan Development Review, 51(4), 565-586.

Nambissan, G. B. (2013). The global economic crisis, poverty and education: a perspective from India. Journal of Education Policy, 25(6), 729-737.

Odhiambo, N. M. (2008). Financial Development in Kenya: A Dynamic Test of the Finance-led Growth Hypothesis. Economic Issues, 13(2), 21-36.

Osterwald-Lenum, M. (1992). A Note With Quantiles Of The Asymptotic Distribution Of The Maximum Likelihood Cointegration Rank Test Statistics. Oxford Bulletin Of Economics And Statistics. Oxford Bulletin Of Economics And Statistics, 54(3), 461-472.

Rahman, M. M. (2011). Causal Relationship Among Education Expenditure, Health Expenditure And GDP: A Case Study For Bangladesh. International Journal of Economics And Finance, 3(3), 149-159.

Raja Aris, R. F. (2021). Teacher Leadership: A Literature Review. Journal of Contemporary Issue and Thought (JCIT), 11(1), 44-51.

Rambeli, N., \& Podivinsky, J. M. (2013). A Study of Exogeneity Tests On Export-Led Growth Hypothesis The Empirical Evidences on Post-Crisis Exchange Rate Regime in Malaysia. International Business Education Journal (IBEJ), 7, 1-15.

Rambeli, N., Hashim, E., \& Marikan, D. A. (2016a). Relationship Between Education Expenditure, Capital, Labor Force And Economic Growth In Malaysia. International Journal Of Academic Research In Business And Social Sciences, 6(12), 459-468.

Rambeli, N., Marikan, D. A., \& Hashim, E. (2016b). The Effect of Foreign Direct Investment, Exports and Employment on Economic Growth Model. International Journal of Academic Research in Business and Social Sciences, 6(11) 361-376.

Rambeli, N., Podivinsky, J. M., \& Jalil, N. A. (2019). The Re-Examination Of The Dynamic Relationship Between Money, Output And Economic Growth In Malaysia. International Journal Of Innovation, Creativity And Change, 5(2), 1812-1834.

Rambeli, N., Podivinsky, J. M., Hashim, A., \& Hashim, E. (2014). Issues on Exchange Rate Volatility \& Exports Nexus - "A Case For ASEAN". Management Research Journal, 3, 164-184. 
Rambeli, N., Hashim, E., Leh, F. C., Hashim, A., \& Jalil, N. A. (2020). The Role of Education Expenditure on Economic Growth Under Recovery Regime of World Economic Crisis. International Journal Of Psychological Rehabilitation, 24(7), 7535-7543.

Romer, P. M. (1990). Capital, Labor, And Productivity. Brookings Papers On Economic Activity. Microeconomics, 1990(1990), 337-367.

Salgur, S. A. (2013). The Importance of Education in Economic Growth. Manager Journal, $18(1), 47-52$.

Sarwar, F., \& Abbasi, A. S. (2013). An In-Depth Analysis of Women's Labor Force Participation in Pakistan. Middle East Journal of Scientific Research,15(2), 208-215.

Shahid, M. (2014). Impact Of Labour Force Participation On Economic Growth In Pakistan. Journal Of Economics And Sustainable Development, 5(11), 89-93.

Sims, C. A. (1972). Money, Income, and Causality. American Economic, 62, 540-552.

Sims, C. A., Stock, J. H., \& Watson, M. W. (1990). Inference in Linear Time Series Models with Unit Roots. Econometrica, 58, 113-144.

Solow, R. M. (1957). Technical, Change And The Aggregate Production Function. Review of Economics And Statistics, 39(3), 312-320.

Sunde, T. (2017). Education Expenditure And Economic Growth In Mauritius: An Application Of The Bounds Testing Approach. (MPRA Working Paper No. 86667). University Library of Munich.

Thomas, D., Beegle, K., Frankenberg, E., Sikoki, B., Strauss, J., \& Teruel, G. (2004). Education in a Crisis. Journal of Development Economics, 74(1), 53-85.

Todo, H. Y., \& Phillips, P. C. B. (1993). Vector Autoregressions and Causality. Econometrica, 61, 1367-1393.

Topcu, E., Altinoz, B., \& Aslan, A. (2020). Global Evidence From The Link Between Economic Growth, Natural Resources, Energy Consumption and Gross Capital Formation. Resources Policy, 66, 101622.

Wasti, S. K. A., Karrar, O., \& Zaidi, S. W. (2017). Impact Of Education Expenditure On The Economic Development. An Empirical Investigation In Case Of Kuwait. International Journal Of Management Sciences And Business Research, 6(11), 90-98.

Yeisa, W., \& Rani, L. N. (2020). Analisis Faktor-Faktor Yang Mempengaruhi Pertumbuhan Ekonomi Di Oki. Jurnal Ekonomi Syariah Teori Dan Terapan, 7(6), 1128-1145. 